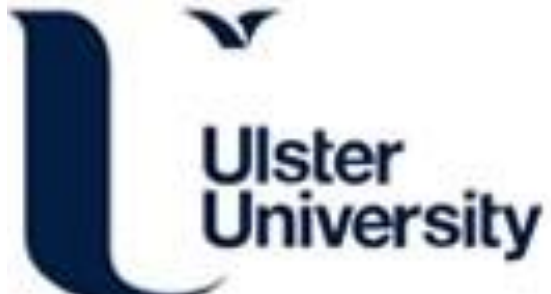

\section{Occupational therapy students' attitudes towards inclusion education in Australia, United Kingdom, United States and Taiwan.}

Mu, K., Brown, T., Peyton, C. G., Rodger, S., Huang, Y-H., Wu, C-Y., Watson, C., Stagnitti, K., Hutton, E., Casey, J., \& Hong, C. S. (2009). Occupational therapy students' attitudes towards inclusion education in Australia, United Kingdom, United States and Taiwan. Occupational Therapy International, 17, 40-52. https://doi.org/10.1002/oti.285

Link to publication record in Ulster University Research Portal

\section{Published in:}

Occupational Therapy International

Publication Status:

Published (in print/issue): 21/08/2009

DOI:

10.1002/oti.285

\section{Document Version}

Publisher's PDF, also known as Version of record

\section{General rights}

Copyright for the publications made accessible via Ulster University's Research Portal is retained by the author(s) and / or other copyright owners and it is a condition of accessing these publications that users recognise and abide by the legal requirements associated with these rights.

\section{Take down policy}

The Research Portal is Ulster University's institutional repository that provides access to Ulster's research outputs. Every effort has been made to ensure that content in the Research Portal does not infringe any person's rights, or applicable UK laws. If you discover content in the Research Portal that you believe breaches copyright or violates any law, please contact pure-support@ulster.ac.uk. 
RESEARCH ARTICLE

\title{
Occupational Therapy Students' Attitudes Towards Inclusion Education in Australia, United Kingdom, United States and Taiwan
}

\author{
Keli Mu*, Ted Brown², Claudia G. Peyton ${ }^{3}$, Sylvia Rodger ${ }^{4}$, Yan-Hua Huang ${ }^{5}$, Chin-Yu Wu ${ }^{6}$, \\ Callie Watson ${ }^{7}$, Karen Stagnitti ${ }^{8}$, Eve Hutton ${ }^{9}$, Jackie Casey ${ }^{10}$ \& Chia Swee Hong ${ }^{11}$ \\ 'Department of Occupational Therapy, School of Pharmacy and Health Professions, Creighton University, Omaha, NE 68178 USA \\ ${ }^{2}$ Department of Occupational Therapy, School of Primary Health Care, Faculty of Medicine, Nursing and Health Sciences, Monash \\ University - Peninsula Campus, Frankston, Victoria, Australia \\ ${ }^{3}$ Department of Occupational Therapy, College of Health and Human Services, California State University, Carson, CA, USA \\ ${ }^{4}$ The University of Queensland, School of Health and Rehabilitation Sciences, Division of Occupational Therapy, Brisbane, Queensland, \\ Australia \\ ${ }^{5}$ Department of Occupational Therapy, College of Medicine, Chang Gung University, Kwei-Shan, Taiwan \\ ${ }^{6}$ School of Occupational Therapy, National Taiwan University, Taipei City, Taiwan \\ ${ }^{7}$ Occupational Therapy Program, College of Saint Mary, Omaha, NE, USA \\ ${ }^{8}$ Occupational Science and Occupational Therapy Program, Faculty of Health, Medicine, Nursing and Behavioural Sciences, Deakin \\ University, Geelong Waterfront Campus, Geelong, Victoria, Australia \\ ${ }^{9}$ Occupational Therapy Program, Faculty of Health and Social Care, Canterbury Christ Church University, Canterbury, Kent, UK \\ ${ }^{10}$ Occupational Therapy Program, School of Health Sciences, University of Ulster, Newtownabbey, Northern Ireland, UK \\ ${ }^{11}$ Occupational Therapy Programme, School of Allied Health Professions University of East Anglia, Norwich, Norfolk, UK
}

\begin{abstract}
This international, cross-cultural study investigated the attitudes of occupational therapy students from Australia, United Kingdom, United States and Taiwan towards inclusive education for students with disabilities. The possible impact of professional education on students' attitudes was also explored. A total of 485 students from 11 entrylevel occupational therapy education programmes from Australia, the United Kingdom, the United Sates and Taiwan participated in the study. Among them, 264 were freshmen (first-year students) and 221 were seniors (final-year students). Data collected from a custom-designed questionnaire were analysed both quantitatively and qualitatively.

In general, the occupational therapy students reported having positive attitudes towards inclusion. Considerable differences, however, existed among the student groups from the four countries. Professional education appeared to have a significant impact on students' attitudes towards inclusion from first year to senior year. Although students were in favour of inclusion, they also cautioned that their support for inclusive practices depended on various factors such as adequate preparation, support and assistance to students with disabilities.

Limitations of the study included the small, convenience sample and different degree structures of the participating programmes. Future research studies need to compare occupational therapy students' attitudes with students from other health care professions. A longitudinal study on the impact of the professional education programme on students' attitudes towards inclusive education is warranted. Copyright ๑ 2009 John Wiley \& Sons, Ltd.
\end{abstract}

\section{Keywords}

cross-cultural survey; inclusion education; paediatric occupational therapy

\section{* Correspondence}

Keli Mu, Department of Occupational Therapy, School of Pharmacy and Health Professions, Creighton University, Omaha, NE 68178 USA Email: kmu@creighton.edu

Published online 21 August 2009 in Wiley InterScience (www.interscience.wiley.com) DOI: 10.1002/oti.285 


\section{Introduction}

Inclusive education is an educational service where students with disabilities receive education alongside their general education peers with appropriate support in the same classroom environment (Vaughn et al., 1996; Odom et al., 2004). Inclusive education has been shown to be beneficial for students with and without disabilities, both socially (e.g., Helmstetter et al., 1994; Kennedy et al., 1997; Mu et al., 2000) and educationally (e.g., Hunt and Goetz, 1997; McDonnell et al., 2002; Rea et al., 2002; Rafferty et al., 2003). Inclusive education has increasingly become more and more common practice in education contexts around the world (Balboni and Pedrabissi, 1995; Wolery et al., 1995; Eagan, 1998; Alghazo et al., 2003; Wilkins and Nietfeld, 2004; Finegan, 2005; Lambe and Bones, 2006).

The inclusive education movement has impacted upon health care professionals (e.g., occupational therapists, physical therapists, speech pathologists, social workers, psychologists) who work with children and their families as well as in education settings (Scruggs and Mastropieri, 1996). In the United States, inclusive education practices have been mandated by federal government legislative requirements to support children with disabilities within integrated school settings. In the United States, The Education for All Handicapped Children Act of 1975 (United States Department of Education, 1975) and the subsequent Individuals with Disabilities Education Act of 1990 (IDEA; United States Department of Education, 1990) mandated that the public education system provide free, appropriate education to students with disabilities in the least restrictive environment. Occupational therapy is considered one of the important related services for students with disabilities (United States Department of Education, 1990). The Individualized Education Plan, mandated by The Education for All Handicapped Children Act of 1975 (United States Department of Education, 1975) and subsequently by the IDEA provided the blueprint in guiding the education and therapy for students with special needs (American Occupational Therapy Association, 1997). Another piece of American federal legislation that impacts paediatric assessment is known as the No Child Left Behind Act of 2001 (United States Department of Education, 2002); school districts/ Boards of Education are required to provide detailed information about the academic performance of students enrolled in their schools. This is obtained through the completion of standardized achievement testing on a large scale.

Despite the increasing popularity of inclusive education and its inevitable impact on school-based occupational therapy practice, the understanding of occupational therapists' attitude towards inclusion and their practice in inclusive environments is limited (Bose, 2004). In a recent cross-sectional survey study, Mu et al. (2007) examined the attitudes of occupational therapy students towards inclusive education and results indicated that entry-level occupational therapy doctoral students had positive attitudes towards inclusive education and school-based occupational therapy practice. Significant differences found between attitudes among different year levels of students suggested that professional educational training might have positive effects on students' attitudes towards inclusive education practices.

The purpose of the current study was to examine occupational therapy students' attitudes towards inclusion from an international, cross-cultural perspective and to investigate the possible impact of progression through education (e.g., first year, final year) on occupational therapy students' attitudes towards inclusion.

\section{Method}

\section{Study design}

The study design was a static, cohort study.

\section{Participants}

A total of 11 occupational therapy programmes across the globe were invited to participate in this study, i.e., three programmes from Australia, three programmes from the United Kingdom, three programmes from the United States and two occupational therapy programmes from Taiwan. All participating programmes were entry-level occupational therapy programmes. One of the three American occupational therapy programmes offered entry-level professional doctorate education and the other two programmes offered entry-level masters. The programmes in Australia, the United Kingdom and Taiwan all offered entry-level undergraduate degrees in occupational therapy. Entrylevel graduate entry occupational therapy master's programmes exist in the United Kingdom and Australia, but only students from undergraduate programmes 
were involved in this study. Description of the participating programmes is displayed in Table 1.

The number of the participating students from the programmes varied. Only freshman and senior students were invited to participate in the study. A detailed delineation of the number of the students and the participating programmes is reported in Table 2.

Inclusion criteria for participants were that they had to be enrolled in an entry-level occupational therapy education programme that was accredited by the World Federation of Occupational Therapists and that they consented to take part in the study.

\section{Instrumentation}

The inclusion attitude questionnaire was originally developed by Mu et al. (2007) and was found to have moderate levels of reliability (Cronbach $\alpha$ of the questionnaire is 0.87 ).

Because of the cross-cultural differences and language issues, appropriate adjustments were made to the questionnaire's phrasing and terminology in Taiwan. The questionnaire was translated into Mandarin Chinese by the fifth author of the study first and then validated by the sixth author of the study.

\section{Procedures}

Ethics committee approval was obtained from each of the 11 universities where the participating occupational therapy programmes are located. Each investigator distributed the questionnaires to the first-year and final-year students and asked them to complete the questionnaires on a voluntary basis. Data was analysed on a group basis and individual participants were not identified.

\section{Data entry, Management and Analysis}

Completed questionnaires from each of the participating programmes were mailed to the first author. Two research assistants of the first author entered the data into the Statistical Program for Social Sciences (SPSS) version 16 (SPSS Inc., Chicago, IL., USA) The first author spot checked the entered data to ensure the accuracy of the data entry. Preliminary analysis was also performed to examine the accuracy of the entered data by examining the possible outliers or data scores falling outside expected parameters, unreasonable data, etc.
Descriptive statistics such as mean, standard deviation, range and percentage were used to depict the demographic information of the participants and their responses to the items of the questionnaire. Analyses of variance $(p<0.05)$ were performed to examine whether or not significant differences existed between variables of interest. A Bonferroni post hoc analysis was used to determine whether any significant differences existed among the participant groups from different continents.

Additional comments from the participants were transcribed and analysed using the content analysis method (Bogdan and Biklen, 1992; Morse and Field, 1995). Specifically, the first two authors of the study reviewed the responses separately to identify repeated words, phrases and ideas that were subsequently categorized as the coding categories. These initial coding categories were then compared, contrasted and refined to generate major categories of the study (Bogdan and Biklen, 1992; Morse and Field, 1995). Next, the two authors shared and discussed their independent findings. When disagreement occurred, the two authors re-examined the data and the analysis results until consensus was reached.

\section{Results}

\section{Participant attitudes to inclusion}

\section{Questionnaire results}

Demographic data related to the student participants is reported in Table 2. The means, standard deviations and ranges of the summed scores on students' attitudes towards inclusive education for each of the participating programmes are reported in Table 3. As seen in Table 3, among the freshmen, students from the United States had the most positive attitudes towards inclusion education, followed by Australian students. Similarly, among seniors, students in the United States and Australia reported more positive attitudes towards inclusion. Unexpectedly, the results of the study revealed that senior occupational therapy students in the United Kingdom and Taiwan indicated less positive attitudes than their freshman peers, while seniors in the United States and Australia held more positive attitudes.

The results of the statistical analysis revealed several significant differences. Among the freshmen's (first year) attitudes, statistically significant differences were found between freshmen in the United States and 
Table 1. A brief description of the participating programmes

\begin{tabular}{|c|c|c|c|c|c|}
\hline & Programme & $\begin{array}{l}\text { Degree } \\
\text { structure }\end{array}$ & $\begin{array}{l}\text { Length of the } \\
\text { programme }\end{array}$ & $\begin{array}{l}\text { Programme focus or programme } \\
\text { goals }\end{array}$ & $\begin{array}{c}\text { Content on paediatrics and } \\
\text { school-based OT }\end{array}$ \\
\hline Australia & Programme 1 & Baccalaureate & 4 years & $\begin{array}{l}\text { The goals of the Deakin programme } \\
\text { are to be responsive, relevant and } \\
\text { innovative in approaches to } \\
\text { education. Students are also } \\
\text { prepared to be workforce ready and } \\
\text { keen to embrace emerging areas of } \\
\text { occupational therapy work. Deakin } \\
\text { is well situated to service rural and } \\
\text { remote centres and cater for } \\
\text { students who have a rural } \\
\text { background. Deakin is the first } \\
\text { university in Australia that requires } \\
\text { students to complete a totally }\end{array}$ & $\begin{array}{l}\text { Students cover child development and } \\
\text { specific paediatric clinical groups from } \\
\text { second year. In third and fourth year } \\
\text { they undertake studies in specific } \\
\text { areas of paediatrics as well as } \\
\text { fieldwork placement in a school } \\
\text { setting, working with students who } \\
\text { require occupational therapy } \\
\text { intervention. During this fieldwork, } \\
\text { they also receive training in a range of } \\
\text { paediatric assessments, interventions, } \\
\text { and issues relating to paediatric } \\
\text { practice. }\end{array}$ \\
\hline
\end{tabular}

Programme 2 Baccalaureate 4 years programme: Bachelor of Occupational Therapy (BOT)
Programme 3 Baccalaureate programme and

graduate

Masters

programme on-line unit of study.

The method of teaching in the undergraduate programme is problem-based learning (PBL). There is also a focus on interprofessional education (IPE) and health promotion and population health. There are no specific units dedicated only to the topic of inclusive education, paediatrics, or attitudes towards persons with a disability, however, given that a PBL approach is used, students often work on cases that involve these topics.

Students also have practical skills sessions, lectures, and tutorials related to these knowledge areas. Therefore, the OT students have contact with these topics in their OT education. Students complete units on evidence-based practice and also take part in a two semester participatory community placement where they partner with a community agency to complete a population health/health promotion project.

4 years for The undergraduate programme Baccalaureate involves a range of teaching and 2 years methodologies including didactic for Master lectures, interactive tutorials, programme seminars and workshops. All courses utilize a BlackBoard ${ }^{\circledR}$ web-based platform where information is posted and discussions can occur. The simultaneous use of classes and BlackBoard ${ }^{\circledR}$ sites is known as blended learning. Students undertake block fieldwork full time in their third and fourth years.
Students do not complete a specific unit on paediatric occupational therapy practice. In their first year, students have lectures on normal human development as well as children's occupations (play, self-care, attending school). During the second and third years of the programmes, students have problem-based learning cases dealing with paediatric diagnostic groups. With these cases, students learn about the clinical issues, occupational therapy role and occupational performance challenges.

Students also have clinical/practical skills tutorial sessions where they learn about assessment tools and specific intervention methods. Students also complete one paediatric fieldwork placement in various settings such as special developmental schools, hospitals, early intervention or community health centres.

Students cover content in intellectual disabilities and children's conditions, as well as the environmental context of service provision (e.g., school settings, community settings) in their second and third years of the programme. Attitudes towards disability and societal perceptions of disability are challenged from the first year in students' interactions with consumers as part of teaching sessions. Social aspects of health and wellbeing are introduced in their second year. 
Table 1. Continued

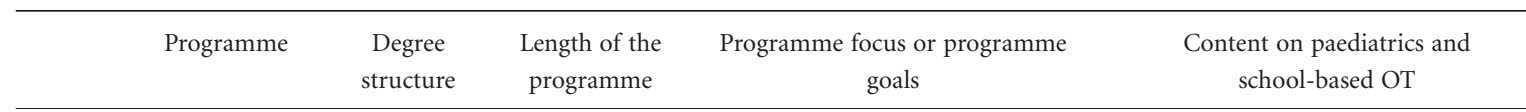

\begin{tabular}{lll}
\hline & & \\
& & \\
& & \\
United & Programme 1 & $\begin{array}{l}\text { Baccalaureate } \\
\text { programme }\end{array}$ \\
Kingdom & & years
\end{tabular}

Prior to this short 2-3-hour clinical sessions in various settings are provided in adult hospital settings, mental health community-based settings and children's clinic.

Kingdom programme

Programme 2 Baccalaureate 3 years programme?
The aims of the programme are to

(1) produce high-quality graduates who have the knowledge and expertise to meet the demands of current and future employment markets; (2) prepare students to be competent, effective, critical and reflective practitioners who appreciate the need for life long learning; (3) enable students to acquire theoretical knowledge, research and professional skills, and practice techniques prescribed by the national and international professional bodies.

Occupational Therapy undergraduate education aims to develop professionals who help people to lead a life that is meaningful to them and is based on the individual's unique occupational choices (doing the things they want to or need to do in a way that they like to be able to do them). Reflecting changes in society and regarding the rights of people with disabilities, Occupational Therapy programmes enable students to understand how illness, disability, the environment and social or economic circumstances impact on the ability of individuals to carry out their chosen occupations and activities.
All students complete two full modules exploring children and young people in the third year of the programme. The first explores typical child development, assessment and interventions for physical and sensory dysfunctions seen in children and young people, as well as understanding of the occupational therapist's role within the school setting, and the various school options available to children (special education and mainstream education, inclusive vs segregated learning). The second module, in semester two, explores intellectual impairments and their impact on occupational functioning and everyday life, as well as psychosocial difficulties and treatment for children and young people. Within these modules attitudes towards both inclusion and towards persons with disabilities is covered in class seminars and informal discussions. The students also receive teaching exploring their own and others' attitudes, values and beliefs within year two modules.

The OT-specific modules have a strong emphasis on occupation and equality which students explore in relation to their own development and to the people therapists might work with. Needs of Children and adolescents are considered in an integrated way in year one and two modules but in year three, students have a specific module on role development of Children and adolescents. 
Table 1. Continued

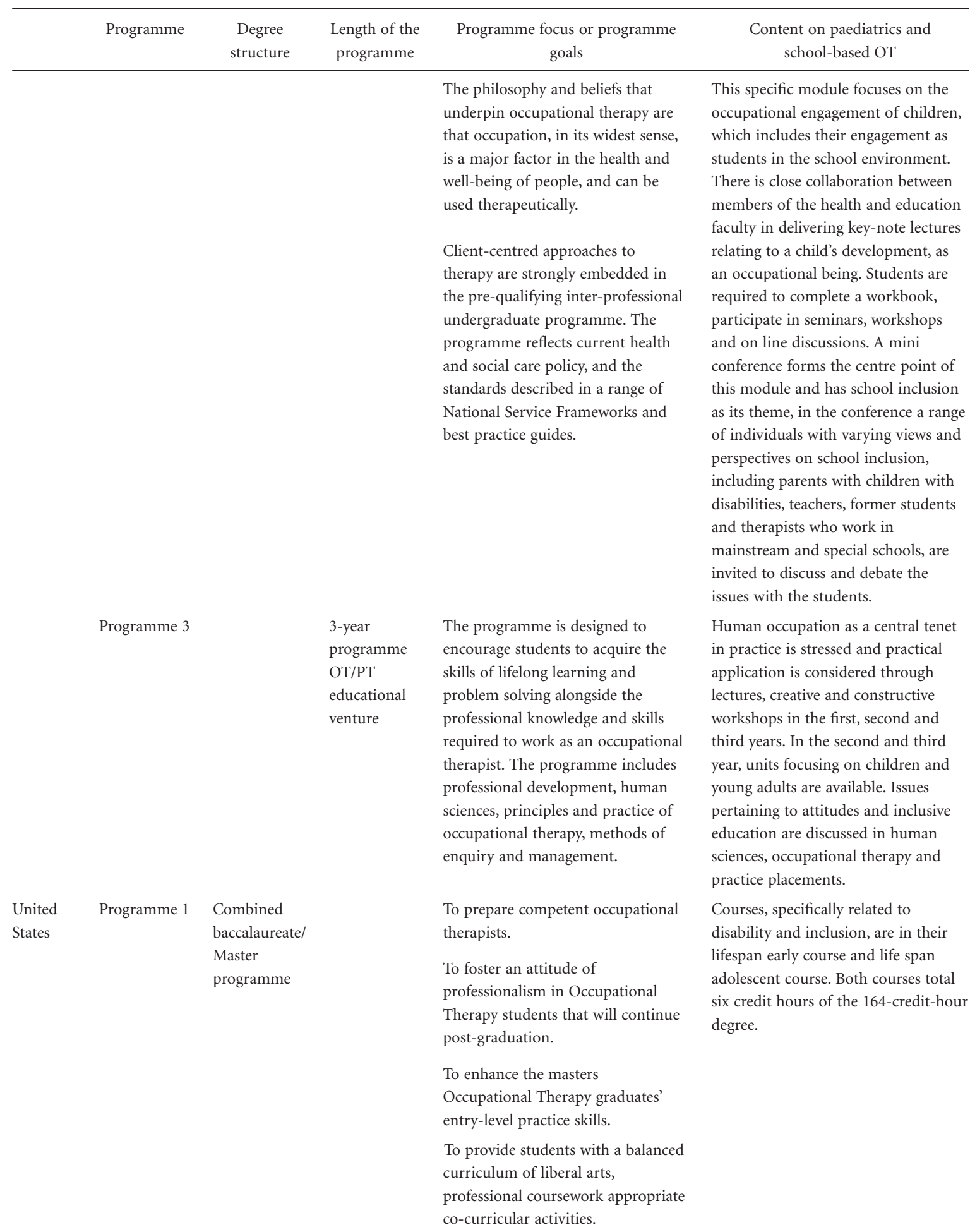


Table 1. Continued

\begin{tabular}{|c|c|c|c|c|c|}
\hline & Programme & $\begin{array}{l}\text { Degree } \\
\text { structure }\end{array}$ & $\begin{array}{l}\text { Length of the } \\
\text { programme }\end{array}$ & $\begin{array}{c}\text { Programme focus or programme } \\
\text { goals }\end{array}$ & $\begin{array}{c}\text { Content on paediatrics and } \\
\text { school-based OT }\end{array}$ \\
\hline & Programme 2 & $\begin{array}{l}\text { Master } \\
\text { programme }\end{array}$ & 2.5 years & $\begin{array}{l}\text { There are four foundational values } \\
\text { and beliefs that are embedded in the } \\
\text { CSUDH Occupational Therapy } \\
\text { Curriculum framework and } \\
\text { philosophies: } \\
\text { 1. Humans are occupational beings. } \\
\text { 2. Occupations. } \\
\text { 3. Person-environment-occupation- } \\
\text { performance perspective. } \\
\text { 4. Professional competency. }\end{array}$ & $\begin{array}{l}\text { The CSUDH MSOT programme } \\
\text { follows a lifespan progression of } \\
\text { course content. Thus, one semester is } \\
\text { devoted to each are of development; } \\
\text { paediatrics, adolescence, adulthood } \\
\text { and older age. A total of six courses } \\
\text { focused on occupational therapy } \\
\text { practice with children and youth are } \\
\text { included in the programme. The six } \\
\text { courses are offered during the first } \\
\text { year of the programme, during the } \\
\text { third semester. }\end{array}$ \\
\hline & Programme 3 & $\begin{array}{l}\text { Clinical } \\
\text { doctoral } \\
\text { programme }\end{array}$ & 3.5 years & $\begin{array}{l}\text { The OTD programme intended to } \\
\text { prepare competent and ethical } \\
\text { occupational therapy practitioners } \\
\text { who not only could fulfil } \\
\text { 'traditional' roles of occupational } \\
\text { therapists (direct health care } \\
\text { providers, consultants, educators, } \\
\text { health care administrators, } \\
\text { researchers, and advocates for the } \\
\text { profession and the consumers), but } \\
\text { could also develop occupational } \\
\text { therapy programming and serve as } \\
\text { leaders in occupational therapy and } \\
\text { health care. }\end{array}$ & $\begin{array}{l}\text { Two three-credit hour courses focused } \\
\text { on occupational therapy practice with } \\
\text { children and youth are included in the } \\
\text { programme. The two courses are } \\
\text { offered during the first year of the } \\
\text { programme, the first one in the Fall } \\
\text { semester of the first year and the } \\
\text { second one in the subsequent Spring } \\
\text { semester. The three credit hours } \\
\text { include two lecture hours and two } \\
\text { laboratories each week during the } \\
\text { semester. }\end{array}$ \\
\hline Taiwan & Programme 1 & $\begin{array}{l}\text { baccalaureate } \\
\text { programme }\end{array}$ & 4 years & $\begin{array}{l}\text { The Department was founded in } \\
\text { accordance to the need of the society } \\
\text { due to the trend towards the aging } \\
\text { society in Taiwan and the } \\
\text { promotion of welfare for the } \\
\text { disabled. The objective of the } \\
\text { Department is to cultivate } \\
\text { outstanding personnel in the clinical } \\
\text { practice and to promote the } \\
\text { professional competence through } \\
\text { the comprehensive and specialized } \\
\text { learning of the basic medicine and } \\
\text { the occupational therapy. }\end{array}$ & $\begin{array}{l}\text { Six 18-week courses (Paediatrics } \\
\text { OT-three, Sensory Intergration: one; } \\
\text { OT Theory and Therapeutic } \\
\text { Techniques-Paediatrics: two; OT for } \\
\text { Developmental Disabilities-Paediatric: } \\
\text { one; OT Therapy and Therapeutic } \\
\text { Techniques: one; and OT for } \\
\text { Psychiatric Conditions in Childhood: } \\
\text { one) - for a total of nine credits of } \\
\text { occupational therapy theory and } \\
\text { practice with children and youth. } \\
\text { These courses are offered during the } \\
\text { second and the third year of the } \\
\text { programme. Two additional courses } \\
\text { (Introduction to OT and OT } \\
\text { Assessments) other than the six } \\
\text { courses contain some paediatric } \\
\text { content for a total of } 14 \text { hours. The } \\
\text { courses Paediatrics OT, OT for } \\
\text { Developmental Disabilities-Paediatric, } \\
\text { and Introduction to OT contain one } \\
\text { class-specific to school-based OT. } \\
\text { Paediatric fieldwork } 2-40 \text { hours per } \\
\text { week for } 13 \text { weeks at the fourth year } \\
\text { of the programme. }\end{array}$ \\
\hline
\end{tabular}


Table 1. Continued

\begin{tabular}{|c|c|c|c|c|}
\hline Programme & $\begin{array}{c}\text { Degree } \\
\text { structure }\end{array}$ & $\begin{array}{l}\text { Length of the } \\
\text { programme }\end{array}$ & $\begin{array}{c}\text { Programme focus or programme } \\
\text { goals }\end{array}$ & $\begin{array}{c}\text { Content on paediatrics and } \\
\text { school-based OT }\end{array}$ \\
\hline Programme 2 & $\begin{array}{l}\text { Baccalaureate } \\
\text { programme }\end{array}$ & 4 years & $\begin{array}{l}\text { The design of curriculum at the OT } \\
\text { Department is more oriented in the } \\
\text { medical model. Throughout the } \\
\text { entire curriculum, current concepts } \\
\text { and practice trends (such as } \\
\text { occupation-based programmes, } \\
\text { client-centredness, community- } \\
\text { based practice, and evidence-based } \\
\text { practice) may be included, but the } \\
\text { amount of hours spent are very } \\
\text { limited. The student outcome of this } \\
\text { programme is leadership in } \\
\text { occupational therapy in the country. }\end{array}$ & $\begin{array}{l}\text { The curriculum contains three credits } \\
\text { on Human Development (including } \\
\text { lab), one credit on Paediatrics lectured } \\
\text { by paediatricians, three credits of } \\
\text { Occupational therapy in Paediatrics } \\
\text { (including practice) which covers } \\
\text { frames of reference, evaluation and } \\
\text { treatment techniques, and } 13 \text { weeks of } \\
\text { full-time fieldwork at clinical facilities. }\end{array}$ \\
\hline
\end{tabular}

Table 2. Demographics of the participants $(n=485)$

\begin{tabular}{|c|c|c|c|c|c|c|c|}
\hline & & & USA & Australia & Taiwan & $\begin{array}{c}\text { United } \\
\text { Kingdom }\end{array}$ & Total \\
\hline \multirow[t]{4}{*}{ Freshmen (first year students) } & Gender & Male & 8 & 2 & 25 & 1 & 36 \\
\hline & & Female & 80 & 52 & 43 & 50 & 225 \\
\hline & & No data & 3 & 0 & 0 & 0 & 3 \\
\hline & Total & & 91 & 54 & 68 & 51 & 264 \\
\hline \multirow[t]{4}{*}{ Seniors (final year students) } & Gender & Male & 8 & 2 & 11 & 4 & 25 \\
\hline & & Female & 53 & 32 & 40 & 70 & 195 \\
\hline & & No data & 1 & 0 & 0 & 0 & 1 \\
\hline & Total & & 62 & 34 & 51 & 74 & 221 \\
\hline
\end{tabular}

Taiwan $(p<0.05)$, and between Australia and Taiwan $(p<0.05)$. Regarding seniors' attitudes, significant differences were found between the United States and Taiwan $(p<0.05)$, Australia and Taiwan $(p<0.05)$, as well as the United States and the United Kingdom $(p<0.05)$.

Within each programme, the difference between freshmen's (first year) and seniors' (final year) attitudes reached significant levels for the programmes in the United States $(p<0.05)$. No significant differences, however, were found between the first-year and finalyear students in the other programmes.

\section{Qualitative results}

Analysis of qualitative data yielded three themes pertaining to participants' perceptions related to inclusion: (1) inclusion: a sense of belonging; (2) support to inclu- sion: it depends; and (3) success of inclusion: knowing how to.

Participants, in general, believed in the philosophy of inclusion. They felt that it was the right of students with disabilities to be included in the general education classrooms. They voiced that inclusion was beneficial to students with and without disabilities as one student stated,

'It's important to include children with disabilities in a regular school setting, because it will teach them and their fellow classmates how to adapt to one another. You can't keep them sheltered forever'.

Another student commented,

'Integrating students with disabilities from early age allows social cohesion and acceptance. If 
Table 3. Mean score for participating programmes from the Inclusion Attitude Questionnaire $(n=485)$

\begin{tabular}{|c|c|c|c|c|}
\hline & Programmes & $\begin{array}{l}\text { Year of the } \\
\text { programme }\end{array}$ & Mean & Range \\
\hline \multirow[t]{6}{*}{ Australia } & \multirow[t]{2}{*}{ Programme 1} & Freshman & 3.46 & 1.94 \\
\hline & & Seniors & 3.43 & 1.61 \\
\hline & \multirow[t]{2}{*}{ Programme 2} & Freshman & 3.48 & 1.22 \\
\hline & & Seniors & 0.0 & 0.0 \\
\hline & \multirow{2}{*}{ Programme 3} & Freshman & 3.49 & 2.11 \\
\hline & & Seniors & 3.44 & 1.61 \\
\hline Total & & & 17.30 & 8.49 \\
\hline \multirow{6}{*}{$\begin{array}{l}\text { United } \\
\quad \text { Kingdom }\end{array}$} & \multirow[t]{2}{*}{ Programme 1} & Freshman & 3.65 & 1.61 \\
\hline & & Seniors & 3.23 & 2.5 \\
\hline & \multirow[t]{2}{*}{ Programme 2} & Freshman & 3.28 & 1.94 \\
\hline & & Seniors & 3.25 & 2.56 \\
\hline & \multirow[t]{2}{*}{ Programme 3} & Freshman & 3.17 & 1.88 \\
\hline & & Seniors & 3.22 & 1.17 \\
\hline Total & & & 19.80 & 11.66 \\
\hline \multirow[t]{6}{*}{ United States } & \multirow[t]{2}{*}{ Programme 1} & Freshman & 3.28 & 2.11 \\
\hline & & Seniors & 3.22 & 1.39 \\
\hline & \multirow{2}{*}{ Programme 2} & Freshman & 3.67 & 1.89 \\
\hline & & Seniors & 3.79 & 1.50 \\
\hline & \multirow[t]{2}{*}{ Programme 3} & Freshman & 3.43 & 2.17 \\
\hline & & Seniors & 3.79 & 1.39 \\
\hline Total & & & 21.18 & 10.45 \\
\hline \multirow[t]{4}{*}{ Taiwan } & \multirow[t]{2}{*}{ Programme 1} & Freshman & 3.06 & 1.84 \\
\hline & & Seniors & 3.18 & 1.72 \\
\hline & \multirow[t]{2}{*}{ Programme 2} & Freshman & 3.14 & 1.94 \\
\hline & & Seniors & 3.03 & 1.39 \\
\hline Total & & & 12.41 & 6.89 \\
\hline
\end{tabular}

children can see those students with disabilities as the same or no different to themselves later in life there will be less looking down towards them'.

Many students commented that their support of inclusion depended on various factors such as the severity of disabilities, grade level of students, attitudes of general peers, training and skills of teachers, and quantity and quality of the support provided. Despite their overall positive attitude towards inclusion, many students cautioned that inclusion is not for every student with disabilities as one student voiced, 'It is difficult to make blanket statements about inclusive education; every situation varies - depending upon the present disability and resources to meet them'. Several other students also expressed similar concerns, for example:

'Many of these questions are dependent on the level of disability of individual students. The level of awareness of students without disabilities and attention to disabled students, academic and social levels'.

'Inclusive education cannot be evaluated under such broad terms - the possible benefits and drawbacks of such must be weighed up for each individual case, rather under the broad terms outlined'.

'I feel that inclusive education for children with disabilities is appropriate on some occasions and not appropriate in other occasions...'

The success of inclusion for students with disabilities, in the views of participating students, largely depended on knowing how to. Students believed that adequate preparation of both students with and without disabilities, training and skills of teachers, proper staff assistance, and resources and support were key factors for successful inclusion. Many voiced such points of view:

'I feel it will stop discrimination taking place and those suffering from a disability will not be marginalized'.

'I know people with severe disabilities who inclusive education has worked for very well. It depends on the individual school and how they deliver their curriculum and education with appropriate support...'

'I believe inclusion has important advantages and disadvantages and needs to be carefully studied to make the best decision for individual students with disabilities'.

Table 4 displays examples of participants' quotes from different programmes of the study.

\section{Discussion}

\section{Occupational therapy students' attitudes to inclusion}

The results of the study revealed that overall, occupational therapy students, including freshmen (first year students) and seniors (final year students), reported positive attitudes towards inclusion. Professional education appears to have a positive impact on students' 
Table 4. Examples of participants' quotes from different programmes

\begin{tabular}{|c|c|c|c|}
\hline Country & School & $\begin{array}{l}\text { Participant } \\
\text { year in } \\
\text { programme }\end{array}$ & Participants' perceptions \\
\hline \multirow[t]{4}{*}{ Australia } & 5 & 1 & $\begin{array}{l}\text { 'It would seem to be ideal if such an "inclusive education" arrangement could be reached } \\
\text { where the needs of general education students and the needs of students with disabilities } \\
\text { could be met simultaneously perhaps Occupational Therapists are the missing link in } \\
\text { general education systems instead of just special needs environments. }\end{array}$ \\
\hline & 5 & 2 & $\begin{array}{l}\text { 'Improvements in educational facilities including teacher resources (time, funding, staff per } \\
\text { child, understanding of disability, etc.) are a must to allow a smooth transition from } \\
\text { separate to inclusive schooling for it to be beneficial for students with or without } \\
\text { disability'. }\end{array}$ \\
\hline & 6 & 1 & $\begin{array}{l}\text { 'I feel that inclusive education for children with disabilities is appropriate on some occasions } \\
\text { and not appropriate in other occasions and is to a certain extent dependent on the type/ } \\
\text { extent of the child's disability and the services available (eg. OT, aide, etc.) that will be } \\
\text { available to the child, as well as support available to children with no disability in the } \\
\text { classroom?. }\end{array}$ \\
\hline & 10 & 1 & $\begin{array}{l}\text { 'Integrating students with disabilities from early age allows social cohesion and acceptance. } \\
\text { If children can see those students with disabilities as the same or no different to } \\
\text { themselves later in life there will be less looking down towards them'. }\end{array}$ \\
\hline \multirow[t]{3}{*}{$\begin{array}{l}\text { United } \\
\text { Kingdom }\end{array}$} & 4 & 1 & $\begin{array}{l}\text { 'I feel it will stop discrimination taking place and those suffering from a disability will not } \\
\text { be marginalized'. }\end{array}$ \\
\hline & 4 & 2 & $\begin{array}{l}\text { 'Inclusive education cannot be evaluated under such broad terms - the possible benefits and } \\
\text { drawbacks of such must be weighed up for each individual case, rather under the broad } \\
\text { terms outlined. }\end{array}$ \\
\hline & 4 & 2 & $\begin{array}{l}\text { 'I know people with severe disabilities who inclusive education has worked for very well. It } \\
\text { depends on the individual school and how they deliver their curriculum and education } \\
\text { with appropriate support'. }\end{array}$ \\
\hline \multirow[t]{5}{*}{ United States } & 2 & 1 & $\begin{array}{l}\text { 'I believe inclusion has important advantages and disadvantages and needs to be carefully } \\
\text { studied to make the best decision for individual students with disabilities'. }\end{array}$ \\
\hline & 2 & 2 & $\begin{array}{l}\text { 'The questions I put "N" on is because the response would depend on the specific context } \\
\text { and type/number of students with disabilities involved' }\end{array}$ \\
\hline & 3 & 1 & $\begin{array}{l}\text { 'It's important to include children with disabilities in a regular school setting, because it will } \\
\text { teach them and their fellow classmates how to adapt to one another. You can't keep them } \\
\text { sheltered forever. Might as well teach them while they're young. }\end{array}$ \\
\hline & 3 & 1 & $\begin{array}{l}\text { 'It is difficult to make blanket statements about inclusive education; every situation varies - } \\
\text { depending upon the present disability and resources to meet them'. }\end{array}$ \\
\hline & 3 & 2 & $\begin{array}{l}\text { 'Many of these questions are dependent on the level of disability of individual students. The } \\
\text { level of awareness of students without disabilities and attention to disabled students, } \\
\text { academic and social levels. }\end{array}$ \\
\hline
\end{tabular}

attitudes towards inclusion in some of the participating programmes, which is evident in that senior/final-year students in the United States and the United Kingdom held more favourable attitudes than their freshman/ first-year peers. The attitude difference between freshmen/first year and seniors/final year, however, reached a statistical significant level only for the students in the United States.

It is not unexpected that considerable variations existed among students' attitudes of different programmes in different countries. One major difference between the programmes in the United States and the other participating programmes is that all American entry-level occupational therapy programmes are at the postgraduate level (e.g., entry-level masters or entrylevel professional doctorates). Whereas in Taiwan, Australia and the United Kingdom, students enrolled in this study were all in undergraduate occupational therapy bachelor's degree education programmes. Hence, students enrolled in American programmes are likely to be slightly older, have more life experience and potentially be more mature in their attitudes.

What the study results also illustrate are differences in the way different countries view inclusion of children with disabilities in inclusive classrooms. Australian and American occupational therapy students appear to have more positive attitudes in general towards inclusion, whereas British and Taiwanese students report less 
positive views. Another factor that may influence occupational therapy students' attitudes towards inclusion is the level, type and duration of clinical fieldwork education placements completed by students. Students in Australia and the United States may have more opportunities to complete fieldwork education placements in school settings or have opportunities to work with children with special needs and their families. This may be also reflective of the types of employment contexts where occupational therapists are working. For example, in the United States, many occupational therapists are employed by state school boards, whereas in Australia, occupational therapists are usually employed by schools that only enrol students with special needs. Very few occupational therapists are employed by school boards to work in inclusive schools in Australia. An additional factor that may account for the differences is the ethos around inclusive education in each respective programme. For example, in the United States, inclusive education is mandated by federal government legislation, whereas in Australia, most children with special needs attend Special Developmental Schools, although some inclusion does occur.

A surprising finding is that senior students held less positive attitudes than first-year students in some of the participating programmes as one would expect in a holistic and humanistic health care profession like occupational therapy, professional education would have a substantial impact on their students' attitudes towards inclusion for students with disabilities. Such a surprising finding may be due to several explanations. First, the structure, curriculum and length of the training of the participating programmes vary considerably. Such differences may have influenced the findings. Secondly, the way in which and the extent to which that each programme addresses the content of paediatrics and inclusion in school-based occupational therapy practice differ substantially which may have contributed to the finding. Lastly, the finding may be simply due to the differences among the students themselves in that individual student's experience of inclusion for students with disabilities are different at the start of the programme. Future research needs to investigate these speculations.

Findings of quantitative data analysis were further echoed by that of qualitative data. It is encouraging to note that participating students believe inclusion is the right of the students with disabilities and inclusion is beneficial for all students. Although in general, students favour inclusion, they were hesitant to fully support such an educational service. They repeatedly cautioned that inclusion is not a blanket statement and is not suitable for all students with disabilities. Practice and success of inclusion depends on many factors and depends on knowing how to put the required components in place to ensure success. It is encouraging to note that students strongly believe that the success of inclusion depends on adequate preparation and support. Such a belief is congruent with previous literature reflecting on students' accurate understanding of the concept of inclusion. Inclusive education is an educational service where students with disabilities receive education alongside their general education peers with appropriate support (Vaughn et al., 1996; Odom et al., 2004). Another encouraging finding was that participating students recognized the value and importance of occupational therapy in facilitating the success of inclusion. They also articulated that appropriate training and preparation for service providers such as teachers and occupational therapists are keys for successful inclusion.

\section{Study limitations}

This study has several limitations. First, participating programmes of the study were recruited via personal contact of the first two study authors. Thus, the samples are convenient in nature and may not be representative of the programmes in the respective geographical regions. Secondly, the degree that each university programme offers varies in level, including baccalaureate, entry-level masters and entry-level clinical doctorate. Lastly, the variety of the educational programme structure, curriculum, language, educational philosophy and terminologies within each university programme may have been biasing factors. However, one common factor of all of the occupational therapy education programmes is that they meet the World Federation of Occupational Therapist accreditation standards in relation to the curriculum taught and fieldwork hours completed by students.

Future studies could be completed where the attitudes towards inclusion and persons with disabilities of occupational therapy students could be compared with those of other health professional student groups (e.g., physiotherapy, speech/language pathology, social workers and nurses). The attitudes of occupational therapy students towards inclusion and persons with 
disabilities could be compared in other non-Englishspeaking cross-cultural contexts, for example, in other Asia-Pacific or European countries. Finally, the impact of a specific education programme about inclusive education and the lived experience of someone with a disability on students could be compared using a prepost- test methodology.

\section{Conclusion}

Occupational therapists often work in education settings alongside classroom teachers and other health care professionals. One education philosophy that is common in many countries is that of the inclusion of children with disabilities into general education classrooms. Occupational therapists often work with children, parents and teachers to promote inclusive practices. Evaluating the attitudes of occupational therapy students towards inclusion of children with disabilities into inclusive classrooms warrants investigation, particularly from an international cross-cultural perspective. The findings of the study indicated that generally first-year occupational therapy students reported less positive attitudes towards inclusion compared with their final-year peers. As well, occupational therapy students from the United States and Australia reported more positive attitudes towards inclusion as a group compared with students enrolled in the United Kingdom and Taiwan.

\section{Acknowledgements}

We are in debt to all occupational therapy students across the globe who participated in this study. Their willingness and efforts to share their point of their view have made this international collaborative project possible.

\section{REFERENCES}

Alghazo EM, Dodeen H, Algaryouti IA (2003). Attitudes of pre-service teachers towards persons with disabilities: predicting for the success of inclusion. College Student Journal 37: 515-522.

American Occupational Therapy Association (1997). Occupational therapy services for children and youth under the Individuals with Disabilities Education Act. Bethesda, MD: American Occupational Therapy Association, Inc.
Balboni G, Pedrabissi L (1995). Attitudes of Italian teachers and parents toward school inclusion of students with mental retardation: the role of experience. Education and Training in Mental Retardation and Developmental Disabilities 35: 148-159.

Bogdan R, Biklen S (1992). Qualitative Research for Education: An Introduction to Theory And Methods (2nd edn). Needham Heights, MA: Allyn and Bacon.

Bose P (2004). Reported experiences of occupational therapists practicing in inclusive early childhood classrooms. Dissertation Abstracts International Section A: Humanities and Social Sciences 65: 824.

Eagan KC (1998). Teacher attitudes toward inclusion: a survey of elementary special and regular education teachers in Massachusetts and New York. Dissertation Abstracts International Section A: Humanities and Social Sciences 59: 1902.

Finegan JE (2005). Teachers' perceptions of their experiences with including students with special needs in the general education classroom setting throughout public and private schools in Texas. Dissertation Abstracts International Section A: Humanities and Social Sciences 65: 4461.

Helmstetter E, Peck CA, Giangreco MF (1994). Outcomes of interaction with peers with moderate and severe disabilities: a statewide survey of high school students. Journal of The Association for Persons with Severe Handicaps 19: 263-276.

Hunt P, Goetz L (1997). Research on inclusive educational programs, practices, and outcomes for students with severe disabilities. Journal of Special Education 31: 3-29.

Kennedy CH, Shukla S, Fryxell D (1997). Comparing the effects of educational placement on the social relationships of intermediate school students with severe disabilities. Exceptional Children 64: 31-47.

Lambe J, Bones R (2006). Student teachers' perceptions about inclusive classroom teaching in Northern Ireland prior to teaching practice experience. European Journal of Special Needs Education 21: 167-186.

McDonnell J, Johnson JW, Polychronis S, Risen, T (2002). Effects of embedded instruction on students with moderate disabilities enrolled in general education classes. Education and Training in Mental Retardation and Developmental Disabilities 37: 363-367.

Morse JM, Field PA (1995). Qualitative Research Methods for Health Professionals. (2nd edn). London: Sage Publications.

Mu K, Siegel E, Allinder, R. (2000). Peer interactions and social relationships of high school students with moderate or severe disabilities in inclusive classrooms. Journal of the Association for Persons with Severe Handicaps 25: 142-152. 
Mu K, Franck LG, Konz C (2007). Attitudes of entry level occupational therapy doctoral students towards inclusion for students with disabilities. Australian Occupational Therapy Journal 54: S66-S73.

Odom SL, Vitztum J, Wolery R, Lieber J, Sandall S, Hanson MJ, Beckman P, Schwartz I, Horn E (2004). Preschool inclusion in the United States: A review of research from an ecological systems perspective. Journal of Research in Special Educational Needs 4: 17-49.

Rafferty Y, Piscitelli V, Boettcher C (2003). The Impact of inclusion on language development and social competence among preschoolers with disabilities. Council for Exceptional Children 69: 467-479.

Rea PL, McLaughlin VL, Walther-Thomas C (2002). Outcomes for students with learning disabilities in inclusive and pullout programs. Council for Exceptional Children 68: 203-222.

Scruggs TE, Mastropieri MA (1996). Teacher perceptions of mainstreaming/inclusion, 1958-1995: a research synthesis. Exceptional Children 63: 59-74.
United States Department of Education (1975). The Education for All Handicapped Children Act of 1975, Pub. L. 94-142, 89 Stat. 773.

United States Department of Education (1990). Individuals with Disabilities Education Act Amendments of 1990, Pub. L. 101-476, 104 Stat. 1103.

Unites States Department of Education (2002). No Child Left Behind Act of 2001, Pub. L. 107-110, 115 Stat. 1425.

Vaughn S, Schumm JS, Jallad, B, Slusher JSaumell L (1996). Teachers' views of inclusion. Learning Disabilities Research and Practice 11: 96-106.

Wilkins T, Nietfeld JL (2004). The effect of a school-wide inclusion training programme upon teachers' attitudes about inclusion. Journal of Research in Special Educational Needs 4: 115-121.

Wolery M, Werts MG, Caldwell NK, Snyder ED, Lisowski L (1995). Experienced teachers' perceptions of resources and supports for inclusion. Education and Training in Mental Retardation and Developmental Disabilities 30: $15-26$. 